\title{
Condition of Water Bodies in the Kazan City Due to the Organization of the Summer World Universiade 2013
}

Derevenskaya 0. Yu. ${ }^{a}$

Mingazova N.N. ${ }^{b}$

Zamaletdinov R.I.c

Pavlova L.R. ${ }^{\mathrm{d}}$

Schigapov I.S.e

abcde Kazan Federal University, Institute of Management, Economics and Finance, Kazan, 420008, Russia

Email: oderevenskaya@mail.ru

\section{Doi:10.5901/mjss.2015.v6n1s3p465}

\section{Abstract}

Assessed the impact of the World Summer Universiade 2013 in Kazan on water bodies. The studies produced material showing a significant effect of a major international competition for the water objects. The greatest impact occurs during the construction of sports facilities. For residents and guests of Kazan were conducted sociological polls. Much of the respondents believe prosperous the situation with natural water objects of the city, although the analysis of the actual situation is not confirmed. The data obtained make it possible to optimize the work associated with the preparation and conduct of major sporting events.

Keywords: international competitions, XXVII World Summer Universiade, environmental impact assessment, water quality, water objects, river Kazanka, Lake Middle Kaban.

\section{Introduction}

Water resources are the most important natural resources of Russia. The most important source meet diverse needs of the person in the water resources are annually renewable surface freshwaters.

Kazan - one of the largest economic, industrial, scientific and cultural centers of Russia. XXVII Summer World University Games in Kazan city was carried out in 2013. It is the second in importance sporting event in the world. The significance of this event is extremely important for the development of Kazan, as well as the Russian Federation [8,11].

Some objects Universiade located in the floodplain of the river Kazanka and Lake Middle Kaban. Rowing competitions were conducted at Lake Middle Kaban. Therefore, the condition of water objects is an important component in characterizing the readiness of the city to hold this major sporting event.

Special Programme for Environmental Protection was implemented in Kazan to improve the environmental situation in the preparation of the Universiade 2013 [10]. This program includes landscaping and purification Lake Middle Kaban (at the location of the Center for Rowing sports); improvement the right bank of the river Kazanka, which were built football stadium "Kazan Arena" and the Center for Water sports.

The holding of major international competitions often has negative trends related to environmental degradation due to the construction of sports facilities for valuable natural areas [1, 2]. The purpose of this work was to study the influence of the Universiade on the condition of the largest water objects of the Kazan city.

\section{Method}

We have developed a methodical approach to assessing the impact of the Universiade 2013 on water quality water objects, as well as methodology for the evaluation this indicator. Indicator status in 2009 was taken as the initial (before the games), taken equal to 1 . Then the indicator to assess changes over certain time periods (Table 1). Evaluation of changes carried out in the following time intervals: 2009 - 2012 years; June 2013 (30 days before the start of the Universiade); Jule 2013 (during the Universiade); August 2013 (30 days after the end of the Universiade); 2014 - $1^{\text {st }}$ 
quarter. These periods allow to evaluate the dynamics of change of the indicator.

To detect changes in water quality of water objects in 2013 were carried out field research, physical and chemical analyzes of water, as well as conducted hydrological measurements (water level). To assess the quality of water was used Ecological and sanitary classification (ESC), based on 4 hydrophysical and 8 hydrochemical indices. In accordance with this water studied object belongs to a certain class and category of water quality with the corresponding rank performance (RP) of ESC [9]. Water pollution index (WPI) was calculated, recommended for formalized integrated assessment of water quality in 6 hydrochemical parameters by formula:

n

$\mathrm{WPI}=1 / \mathrm{n}^{*} \sum \mathrm{C}_{\mathrm{i}} / \mathrm{PDK}$

$\mathrm{i}=1$

where $C_{i}$ - concentration of the component; $n$ - the number of indicators used to calculate the index, $n=6 ; M P C_{i}$ set value standard for the type of water body; MPC - maximum permissible concentration [3].

In order to assess changes in the indicator were used fund materials of Laboratories water ecosystems optimization KFU $[4,5]$.

As part of the work carried out by specialized sociological polls. The main purpose of the survey was to assess the environmental culture through the evaluation results of a poll of citizens and Kazan Universiade guests about the impact on the city environment. The results of the poll were the basis for assessing the status indicator, allowed us to estimate the public reaction to the changes that have taken place in Kazan for the period of preparation and holding of the Universiade. A total of 1,671 respondents were interviewed (residents and guests).

\section{Result}

Organization and holding of the Universiade 2013 in Kazan were adjoint to the impact on water bodies, due to the construction and operation of sports facilities, as well as the construction of infrastructure objects.

The impact on the water objects in the preparation and carrying out of the Universiade was an ambiguous in terms of the assessment of the status of water objects. During the construction of sports facilities (2010-2012 years) the impact was mostly negative, especially on the river Kazanka. During the construction of sports facilities in the floodplain of the river in its lower reaches were backfilled and destroyed with large areas of wetlands (about 60 hectares). In the shallow waters of the river Kazanka previously grew higher aquatic vegetation. This complex submerged macrophytes, algae and bacteria perform a very important function of natural bio filter. Shoals is a place of natural self-cleansing of the river, was the site of spawning phytophilic fish species, rare species of plants. In addition, during the construction of sports facilities in water objects has received a large amount of suspended solids and oil from working construction vehicles. All this led to the deterioration of the ecological status of water objects for some indicators (Table. 1).

Lake Middle Kaban has a significant impact conditionally clean industrial wastewater and untreated sewage storm water drain [5]. Coastal protection, clearing of debris, landscaping were made when creating the rowing canal. At the same time were covered with shallow areas involved in self-purification of the lake water. Wastewater treatment plants, which were planned to be constructed for stormwater issues, were not built.

Direct impact on the Kuibyshev reservoir and the river Kama in the construction of the Universiade is not revealed $[6,7]$.

Table 1. Integral assessment of changes in water quality over the study period

\begin{tabular}{|c|c|c|c|c|c|c|c|c|}
\hline Indicator & 2009 & 2010 & 2011 & 2012 & June 2013 & July 2013 & August2013 & 2014 \\
\hline Water quality & 1 & 0,7 & 0,8 & 0,7 & 0,90 & 0,8 & 0,8 & 0,8 \\
\hline \multicolumn{9}{|l|}{ Water Pollution Index } \\
\hline Kuibyshev reservoir & 1,4 & 1,7 & 1,5 & 2,7 & $\mathrm{X}$ & 1,8 & $X$ & $X$ \\
\hline Kama river & $X$ & 1,9 & 1,1 & 1,3 & $\mathrm{X}$ & 1,4 & $X$ & $X$ \\
\hline Kazanka river & 1,7 & 2,4 & 1,7 & 1,8 & 1,0 & 0,9 & 2,7 & 2,7 \\
\hline Lake Middle Kaban & 0,7 & 1,9 & 1,1 & 1,1 & 1,0 & 1,1 & 0,6 & 0,6 \\
\hline Lake Lower Kaban & 2,1 & $x$ & $x$ & $\mathrm{X}$ & 1,3 & 1,0 & 0,9 & 0,9 \\
\hline Lake Upper Kaban & 0,6 & $X$ & $X$ & $\mathrm{X}$ & 0,8 & 0,8 & 0,9 & 0,9 \\
\hline \multicolumn{9}{|l|}{ Water level, $\mathrm{m}$ BS } \\
\hline Kuibyshev reservoir & 52,88 & 52,7 & 52,8 & 53,00 & $\mathrm{X}$ & $X$ & $\mathrm{X}$ & $\mathrm{X}$ \\
\hline Kama river & 62 & 62 & 62 & 62 & $\mathrm{X}$ & $X$ & $\mathrm{X}$ & $\mathrm{X}$ \\
\hline Kazanka river & 52,88 & $x$ & $x$ & 53,00 & 53,08 & 52,63 & 52,65 & 52,65 \\
\hline Lake Middle Kaban & 51 & $x$ & $x$ & 50,8 & 50,9 & 51 & 51 & 51 \\
\hline
\end{tabular}

Note: $\mathrm{X}$ - no data available. 
During the field research, we analyzed the water quality of the river Kazanka and lakes Upper, Middle and Lower Kaban on a number of indicators. Analysis of the data shows that the water of the surface layer of the Kaban lakes characterized as "very pure" - "pure enough" for ESC and as a "pure" - "moderately polluted" by the WPI. At the same time the water quality of the bottom layer is significantly lower due to water stratification, lack of aeration and mixing in the water column. The highest values of WPI associated with deficiency of oxygen in the bottom layer. It should be noted the high RP ESC and WPI in the water of the bottom layer of the Lake Lower Kaban equal to 6.7 ("strongly polluted" water) and 26.7 ("extremely dirty" water). This is due to strong organic pollution of water objects (high values of Chemical Oxygen Demand (COD), Biochemical Oxygen Demand ( $\left.\mathrm{BOD}_{5}\right)$, a high content of ammonium and phosphates) and oxygen deficiency. Water is the bottom layer of the Lake Upper Kaban characterized as "weakly polluted" by RP ESC and as "polluted" by WPI. It also reduced the oxygen content increased values of COD and BOD5, ammonium content exceeds the norm. Water is the bottom layer of the Lake Middle Kaban during the study period contained a large amount of organic matter, characterized by "pollution" (08/07/2013) to "extremely dirty" (06/27/2013).

In the period from June to August 2013 not observed trends of deteriorating water quality indicators, which could be interpreted as a result of the impact of the Universiade. Fluctuations in water quality of the lake associated with the accumulation of organic matter in the bottom layer during the growing season, the shortage of oxygen and a constant flow of pollutants (particularly oil). There was no negative impact of directly competitions of water during the Universiade.

As for the water quality of the river Kazanka, during June and July 2013 the water was characterized by "very pure" to "slightly contaminated" by RP ESC and from the "clean" to "moderately polluted" by WPI. In August, there was a significant deterioration in water quality, which was characterized by "weak" to "highly contaminated" by RP ESC and by "pollution" to "dirty" WPI.

When comparing the water quality of the river Kazanka for 5 years of research obviously a gradual increase in the average RP. The greatest value of this indicator is marked in 2013 and corresponds to the category of "slightly contaminated" water (Fig. 1). Water pollution index varies from year to year and in 2013, describes the water of the river as "moderately polluted".

The dynamics of water quality of the surface layer of the Lake Middle Kaban is calmer. Average ranking indicators are within the category of "sufficiently pure" water throughout the study period (Fig. 2). WPI characterized the water of the lake from the "pure" to "moderately polluted", and in 2013 the average WPI comply with class "pure" water.

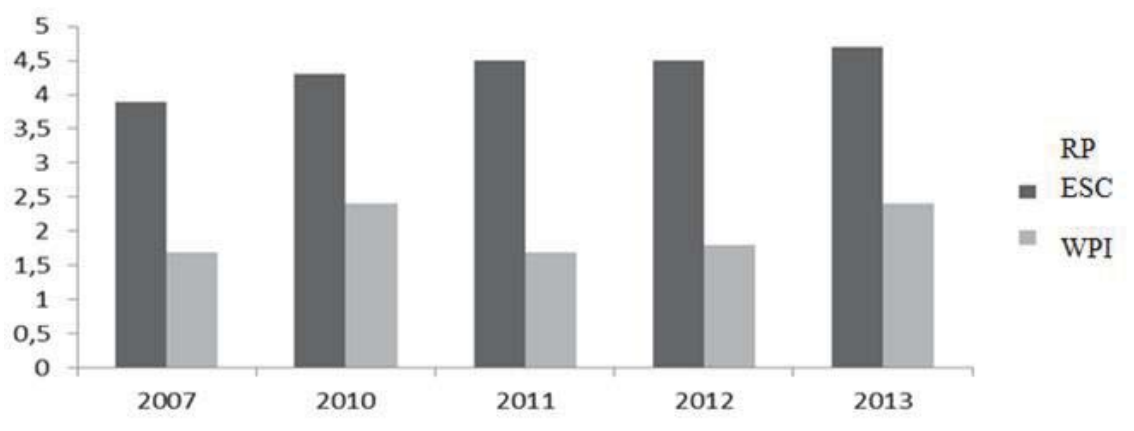

Fig. 1. Dynamics of water quality change in the river Kazanka.

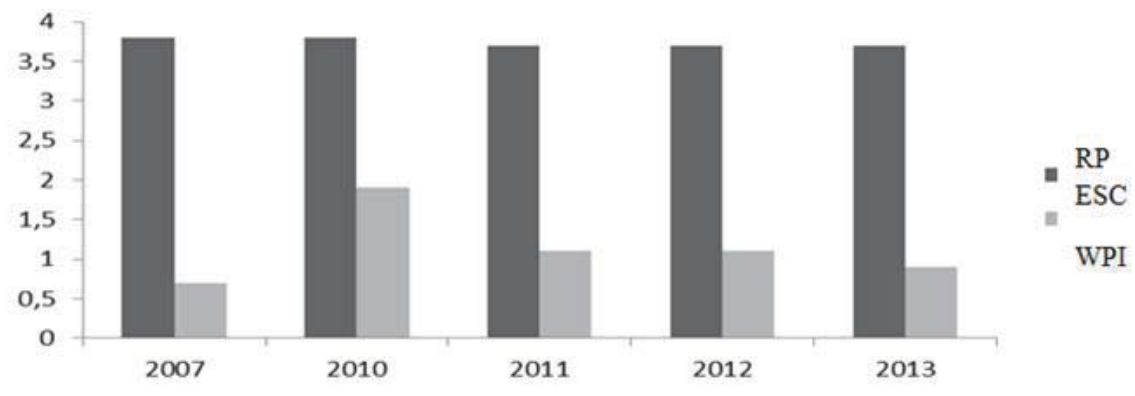

Fig. 2. Dynamics of water quality changes of the Lake Middle Kaban surface layer. 
Field studies were accompanied by an opinion poll. Respondents were asked questions about the condition of water objects and water quality changes in them. According to the poll, $28.4 \%$ of respondents believe that the work on preparation and carrying out of the Universiade a positive impact on the ecological condition of the river Kazanka. 26.9\% of respondents tend to believe that the work had a neutral impact on the river state. A certain part of the respondents say negative (17.5\%) and bad effects (5.6\%) on the ecological state of the Kazanka river works on preparation and holding of the Universiade. It should be noted that $20.0 \%$ of respondents could not answer this question.

Equal number of respondents believe that the ecological state of the Kazanka river correspond (38.2\%) or did not correspond (34.0\%) with the requirements of the Universiade 2013 in Kazan. On this question difficult to answer $28.4 \%$ of respondents.

Otherwise the results of the survey were distributed on the same questions in respect of Middle Kaban Lake. So, on the question of the impact of work on preparation and carrying out of the Universiade on the ecological state of Middle Kaban Lake $38.18 \%$ of respondents believe that a positive, $22.14 \%$ - neutral, $12.51 \%$ - negative and $2.39 \%$ - adversily. This question is a significant number of respondents were undecided - $23 \%$.

The question of compliance with the ecological state of the Lake Middle Kaban requirements Universiade revealed the following picture. Much of the respondents (44.4\%) believe that the correspondence. Significantly smaller amount (23.9\%) thinks that does not match. A significant number of respondents (29.98\%) were undecided.

The results of the sociological polls showed that a large part of the population of Kazan and guests believe the favorable state of natural reservoirs of the city. This opinion does not coincide with the actual results of field research. This can be partially explained by the fact that the residents and guests of Kazan Universiade much less aware of the situation with Lake Middle Kaban. The situation for the river Kazanka is familiar to many citizens, including those on public opposition to the destruction of valuable wetland floodplains in the place where a Universiade key objects are built. Also, to a certain extent triggers patriotic mood when activation sports victory [11] obscures environmental problems and they become less significant. This example can be seen in a certain degree of transformation of environmental awareness.

\section{Conclusion}

On the basis of the material revealed a negative impact on natural water objects during the construction of the Universiade. In preparation for the Universiade was covered with sand of the river Kazanka floodplain. This led to a decrease in the ability of the river to purification, to the deterioration of water quality in many respects, to the destruction of habitats of aquatic organisms and fish spawning areas. Influence of preparation and holding of the Universiade on the Kuibyshev reservoir and the river Kama not revealed. Much of the population of Kazan Universiade and guests believes prosperous the situation with natural water objects of the city that does not fully coincide with the results of field studies.

Our data provide an opportunity to optimize the work associated with the preparation and conduct of major sporting events.

\section{References}

Derevenskaya O.Yu., Mingazova N.M., Mingaliev R.R., Pavlova L.R. Assessing Economic Losses of the Small River Ecosystems and Developing of Compensation Measures within the Framework of Sports Facilities Construction // Mediterranean Journal of Social Sciences. MCSER Publishing, Rome-Italy. 2014. - P. 345-348.

Malfas M., Theodoraki E., Houlihan B. (2004) Impacts of the Olympic Games as mega-events, Proceedings of the Institution of Civil Engineers: Municipal Engineer. - 2004. Issue ME3. - P. 209-220.

Methodological Guide for formal assessment of water quality. - M: Gidrometeoizdat, 1989. - 287 p.

Mingazova N., Derevenskaya O., Barieva F., Pavlova L. Restoration of Low Kaban Lake (Kazan, Russia): 25-term experience of restoration and monitoring of ecological condition // 13th World Lake Conference. Abstract Volume. Wuhan-China, 2009. - P. 299-305.

Mingazova N.M., Derevenskaya O.Y., Nabeeva E.G., Palagushkina O.V., Unkovskaya E.N., Ahatova V.M., Pavlova L.R., Barieva F.F. The concept of biological rehabilitation of Lake Kaban in city Kazan on the base of condition monitoring // Ecological systems and devices. 2011, № 3, -P. 3-9 (in Russian).

Mingazova N.M., Nikitin A.V., Yupina G.A., Derevenskaya O.Yu. Strategy of Management of City Development with Using «Green» Technologies (Kazan City, Russia) // Mediterranean Journal of Social Sciences. MCSER Publishing, Rome-Italy. 2014. - P. 341343.

Mingazova N.M., Yupina G.A., Derevenskaya O.Yu., Illarionova M.N. Ecology. Environment. Water bodies and green areas. // Urban revitalization and redevelopment of Volga district territories in the city of Kazan (Center Waterfront Area of Volga River). International Urban design workshop. Background information. - Kazan, 2008. - P. 24- 25. 
Mingazova N.M, Zamaletdinov R.I., Safiulin L.N., Gafurov I.R., Bagautdinova N.G., Panasiuc M.V., Glebova I.S. Organizational aspects of the study of influence of the XXVII World Summer Universiade 2013 in Kazan on the development and the region /I International scientific-practical conference «Heritage major sporting events as a socio-cultural and economic development of the region»: Proceedings. - Kazan, 2013. -P.19-21 (in Russian).

Bagautdinova, N.G., Panasyuk, M.V., Gafurov, I.R. Wavelet analysis of the territorial socio-economic system dynamics // World Applied Sciences Journal, 27(13), 2013, 62-66.

Kinossian, N.V. (2008). The politics of the city image: The resurrection of the Kul-Sharif Mosque in the Kazan Kremlin (1995-2005). Architectural Theory Review, 13 (2), pp. 188-205.

Romanenko V.D., Oksiyuk O.A., Zhukinsky V.N. et al. Environmental impact assessment of hydraulic engineering construction on water bodies. - Kiev Naukova Dumka, 1990. - 256 p. (in Russian).

The concept of environmental protection in the preparation and conduct of the XXVII World Summer Universiade 2013 in Kazan with the action plan / FSI UralNII «Ecology», 2010. -123 p. (in Russian).

Zamaletdinov R., Kornilov P., Mingazova N., Dautov A. Transformation of Social and Environmental Views during the Sporting Events (on an Example of the Kazan Universiade 2013) // Mediterranean Journal of Social Sciences. MCSER Publishing, Rome-Italy. 2014. - P. 235-239.

Smirnova, E.V., Urazmetov, I.A. (2014). Specifics of land cover of natural anthropogenic landscapes in oil production regions. International Multidisciplinary Scientific GeoConference Surveying Geology and Mining Ecology Management, SGEM, 1, pp. 765770.

Panasyuk M.V., Pudovik E.M., Sabirova M.E. Problems of labor market of modern Russia in conditions of stable economic growth. Life Science Journal 2014; 11(6s): 487 - 489. 